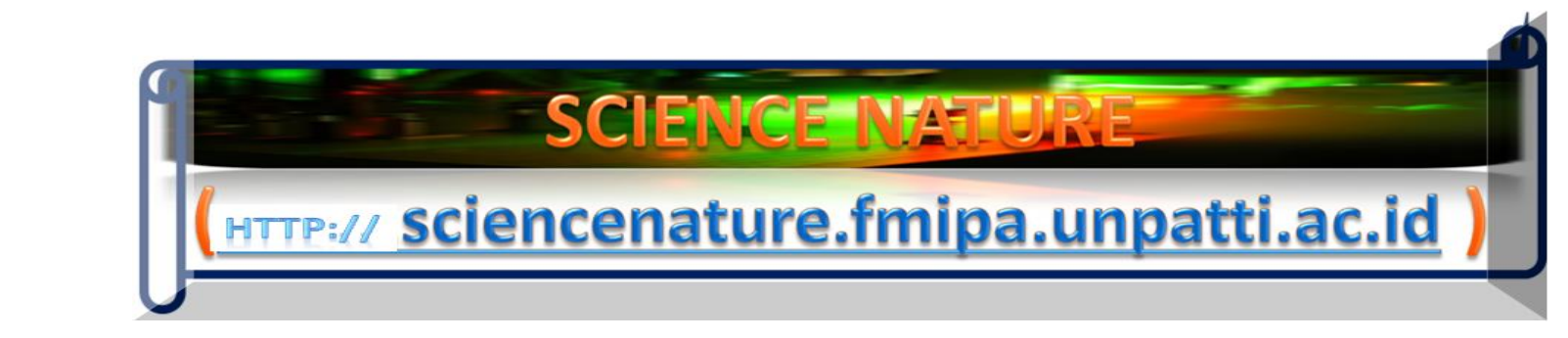

Science Nature 2(3), pp.167-176 (2019)

e-ISSN: 2654-6264

DOI: https://doi.org/10.30598/SNVol2Iss3pp167-176year2019

\title{
The Culture of Sasi In Babar Islands: Traditional and Church
}

\section{Wisdom}

\author{
Tanwey G. Ratumanan ${ }^{1, *}$, J. E. R. Marantika ${ }^{2}$ and Efilina Kissiya ${ }^{3}$ \\ ${ }^{1}$ Mathematics Education Department, Faculty of Education and Teacher Training, Pattimura University, \\ Jl. Ir. M. Putuhena, Poka, Ambon, Indonesia 97233 \\ ${ }^{2}$ Germany Education Department, Faculty of Education and Teacher Training, Pattimura University, \\ J1. Ir. M. Putuhena, Poka, Ambon, Indonesia 97233 \\ ${ }^{3}$ Faculty of Education and Teacher Training, Pattimura University, \\ J1. Ir. M. Putuhena, Poka, Ambon, Indonesia 97233
}

Received : August 1, 2019

Revised : August 29, 2019

Published : September 2, 2019

Copyright @ All rights are reserved by Tanwey G. Ratumanan. J. E. R. Marantika, and Efilina Kissiya Corresponding author: Email: " gratumanan@yahoo.com 
Sasi is a culture that is still practiced and preserved in Maluku province in general and in Babar islands in particular until today. Sasi is a form of prevention of taking natural resources both land and sea within a certain period to let them grow and develop. The Babar islands are known for two types of Sasi, the traditional and the church. Currently, the implementation of Sasi is more dominated by the church - the traditional Sasi is rarely implemented. Sasi provides some benefits both to the environment and community. These benefits include preserved natural resources before harvest, economy increase, public appreciation encouragement, build-up social interaction, and prevention of theft. The long-term application of Sasi consistently will develop positive values of each member in the community, such as (1) appreciation to the environment, (2) devoted to custom rules, and (3) intimacy and mutual share.

Keywords: Sasi, Babar Islands, Long-term application, Benefit.

\section{ARTICLES}

\section{INTRODUCTION}

Customary international laws in a big number of small islands recently have received incredible attention [1] that was very closely associated with Sasi culture in Aru islands region of Maluku province. Current cultural and educational development system [2-18] using local wisdom deep research in Babar islands [2] have made a progress in developing local people in small islands like areas.

Cultural experiences and its development during history have shaped the current Indonesian culture [9-10]. Culture plays
The invented contribution: The benefits and long-term application of both traditional and church Sasi in small islands such as Babar islands.
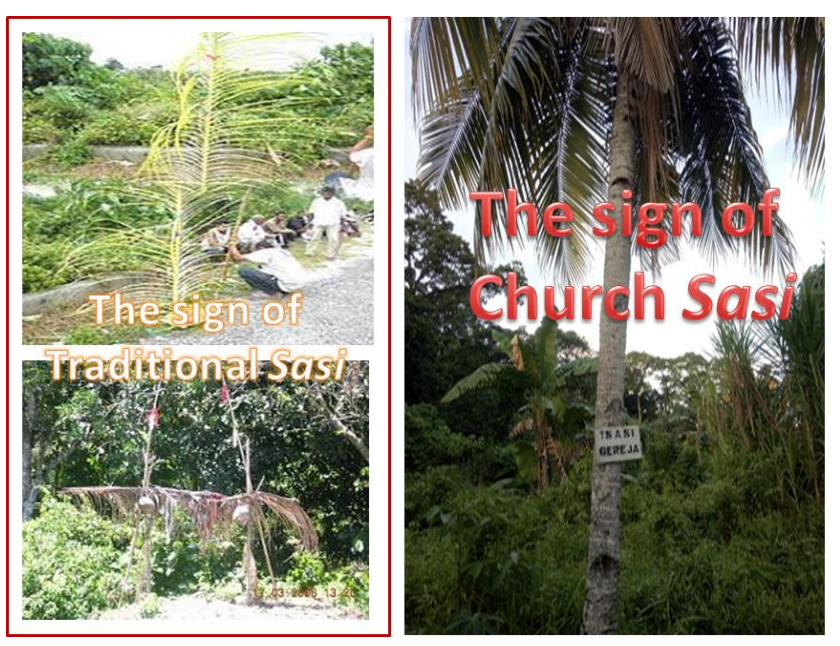

important roles in our lives like education, consolidator, identity, entertainment, and many more.

A universal culture that is defined as emotional or social intelligence, as well as spiritual reflected in local cultural practices in both oral and written forms of knowledge and behavior is called local wisdom. It is built from generation to generation as a solution to every problem. The principal values in local wisdom have become a reference for the local community [7].

Babar Islands is rich with local wisdom which grows and becomes the characteristics of the community. They are (1) greetings, (2) Nyekora or Narera, (3)Neyolya and Nekoila, (4) Kalwedo, (5) Twa-Roona, (6) Nweleya, (7) 
Sasi, (8) Barter, (9) Sopi as custom item, (10) Bameti and Balobe, (11) Niolilieta, (12) traditional songs, (13) tiarka (diarka), (14) traditional games, (15) wedding ritual, (16) traditional clothes, (17) helping out culture, etc $[\mathbf{1 5 , 1 6}]$.

Sasi, a typical culture of Maluku and Babar islands relates to the preservation of the environment and natural resources that are still well-preserved until today. Sasi has become one of the local wisdom in sustaining land and sea resources which are managed by traditional norms. Some traditional rituals must be done either in determining the opening and closing Sasi, the harvest, and penalty for the violator. Lola (a kind of local sea shell), Taripang (sea cucumber), Batulaga, and coconuts are Sasi items in Babar islands. This article will further discuss the implementation of the Sasi culture in Babar islands.

\section{RESEARCH METHODS}

This study is qualitative research with a phenomenological approach. According to Creswell's opinion [4], this research describes respondents' experiences and opinions about Sasi. The respondents are custom figures and community leaders in Babar Island who experience and practice Sasi to get strong understanding and perception about Sasi itself.

This study is qualitative research with a phenomenological approach. According to Cresswel's view [4], this research describes respondents' experiences and opinions about Sasi. The respondents are custom figures and community leaders in Babar Island who experience and practice Sasi to get strong understanding and perception about Sasi itself.

\section{RESULTS AND DISCUSSION}

\subsection{Sasi culture in Babar Island}

Sasi is local wisdom that protects the sustainability of natural resources. There is a debate about the original word of Sasi. It is seen as a legal system [11] where it is one of the social resources or social capital of Maluku to create social harmony [12]. During Sasi, the people are forbidden to collect certain fruits [8] and take the items from the sea for a certain period determined by the government [3].

Sasi is well-known and applied in the daily life of Maluku and Southwest Maluku Regency. Nobody knows exactly when Sasi was practiced in Barbar island. The people believe that it has been performed by their ancestors. In Southwest regency, Sasi is known by several terms. People in Kisar island call it Lu Ira (Woirata) and Hewere (Meher), Nyertuyarna in Romang Island, Matoa in Luang and Sermata islands, Ner'ti, in Babar and Wetang islands, and Weira in Masela island [13].

The following is the information from the interview with the community leaders in Babar island:

"Sasi or known as Ner'ti in west Barbar is still existed and prevents taking farming and sea products in a certain period. It can be done based on the request of a family or clan and state government decision. The family request can do Sasi for their farming product (i.e. coconut). Sasi which is based on the demand of the clan is carried out in the possession of their clan. Sasi which is based on the state government's decision is done by natural results in territories ruled by the state. Sasi increases the economic for the villagers or the 
landlords and keeps the natural resources from extinction.

(Konny Mosse, a custom figure of Tepa village, Babar Island)

"Sasi attaches all the people in Babar island to prevent them from taking the natural resources during Sasi period. In Wetang, the traditional Sasi is conducted in Lakpona by the customs figure in traditional ways while church Sasi is done at church during the service leads by the pastor."

(Yan Watimry, a custom figure in Wetang Island)

"Sasi (including in Luang and Sermatang) is a prohibition against the retrieval of goods (in farms or territories) in a particular period by the owner or by the state (village). It is done based on the request of an individual or the landlords. It is also can be done based on people initiative over the natural resources own by the village. Traditional and Church Sasi are most known by the people in Luang and Sermatang. The traditional Sasi is held in an old house of the head of the clan if they do Sasi for the garden or land. On the other hand, Sasi on the villagers' initiative is conducted at the village hall by custom figures. The church Sasi is done at church through prayer request of an individual or family for their possession that is going to be Sasi."

(Adolf Saleky, a community leader from Luang Island)

"Sasi is a culture that is still practiced in Dawelor, Dawera. It is a protection to the crops and seafood to be harvested at the right time. Sasi is also intended to protect the plantation (coconut, orange, cassava, corn, etc) or seafood (Lola, Batulaga, Teripang, etc) from the unrighteous. Church Sasi is only applied in this village."

(Saul Kapressy, a community leader from

Dawelor Dawera)

"Sasi is a prohibition form of taking yields and seafood in a certain period as needed. It also protects the outcome of Sasi. Church Sasi is the only who applied and practiced in Masela island while traditional Sasi is no longer practiced. The interesting thing is, although Sasi Meti is done in a church way, the symbol of the traditional Sasi which is coconut leaves settled in the middle of Meti is used. Sasi has two principal values: (1) protects the rights of farm owners or landlords and (2) protects the natural resources to grow well before harvest."

(Rev. V. Untailawan, a community leader from Masela Island)

From the explanation above, it is clear that Sasi is known as a prohibition from taking particular natural resources in a certain period. It is done by demand of an individual, a family, a clan, or a village toward their possessions. In Babar islands, Sasi which based on an individual, family, or a clan request, will be done toward their farming products such as coconut, orange, etc. Sasi is also done on Meti for the family land border. The village also can do Sasi for certain products in the possession of the village for example sea products, such as Taripang, Lola, Batu Laga, and so forth.

There are two types of Sasi in Babar islands, traditional Sasi and church Sasi. 
Traditional Sasi is done traditionally while church Sasi is done during the Sunday worship at church. Currently, Sasi is dominated by church although there are still families or villages that carried out traditional Sasi. Both Sasi is done in two phases. First, closing Sasi, a ritual to declare the prohibition of taking products in Sasi Area. Second, opening Sasi to announce that the products are ready for harvest.

Moreover, there are two ways to inform the public regarding the existence of Sasi. In the traditional Sasi, the announcement of Sasi on-farm or land is be delivered orally by Marinyo (a messenger) during the event, then put the "coconut leaves" as the symbol of the Sasi process in Sasi area.
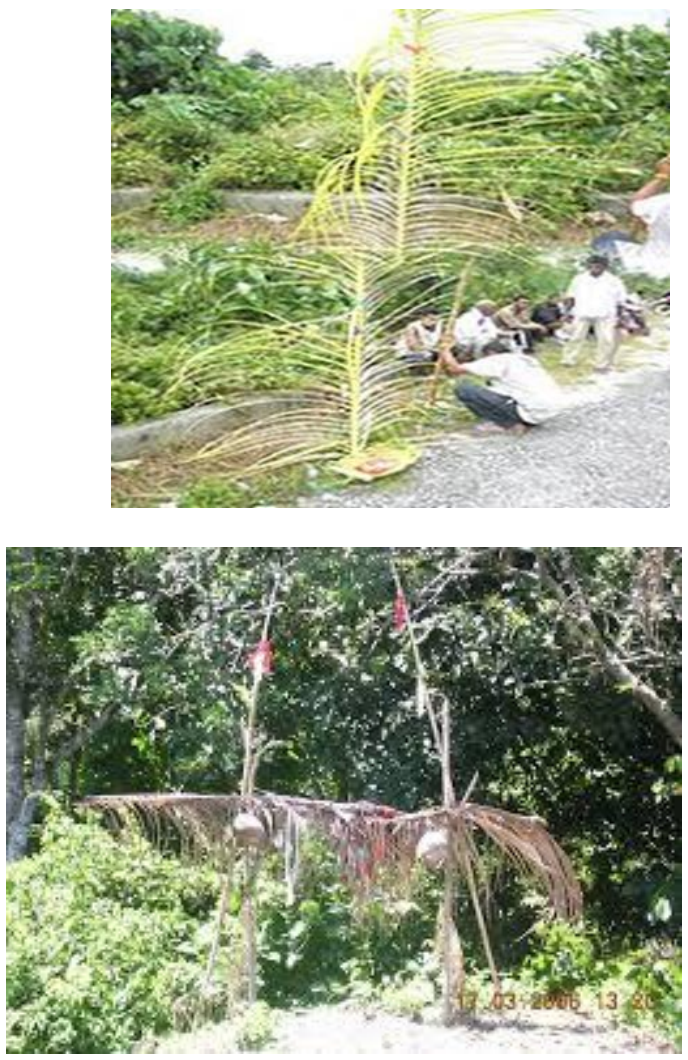

Figure 1. The Sign of Traditional Sasi.
In church Sasi, the information is delivered through church news during Sunday worship at church. Later, after church, the owner of the farm or landlord puts the board written "the Church Sasi" as an announcement to the public that the area is doing Sasi.

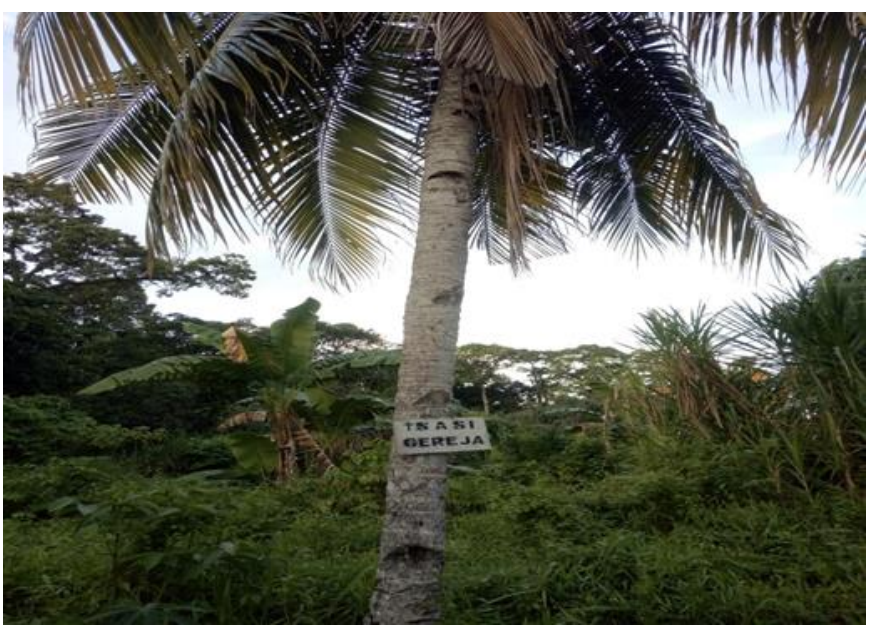

Figure 2. The Sign of Church Sasi.

Sasi is a system that prevents people to take or utilize certain resources at a particular time. Sasi provides several benefits for individuals, families, and villages. They are $[\mathbf{1 3}, \mathbf{1 7}]$ :

1. To secure natural resources preservation. Taking natural resources without restriction will result in extinction. Taking Teripang and Lola at the shore and in the ocean at a certain area without control leads to taking all the size which are not ready for harvest. It decreases the numbers of Teripang and Lola and will be extinct in a certain time. Sasi allows natural resources to remain preserved before being harvested, to grow optimally, remain sustainable, and balance the ecosystem.

2. To increase community income. The system of Sasi contributes to the production or availability of such resources so it can provide sustainable economic impact on the 
owner or the community. It helps the resources to grow ideally to have better size and quality in the harvest and bring high economic impact to the community.

3. The existence of Sasi will impact the community appreciation to the environment. Natural resources and the environment will be maintained and preserved by the time for the opening Sasi.

4. To increase interaction and social relations among people. During the opening of Sasi, when the harvest is abundant, the owner needs people to help him out. The interaction and social relation will be more developed between the owner and the surroundings. In Sasi Meti done by a family, people are even invited to join and take part in the harvest after the opening. The social relationship becomes closer as it brings joy to all who involved in that event.

5. To prevent taking the natural resources and sea product from the theft. The Babar people believe that those who take the farm or seafood products who are being Sasi will be punished by the Almighty.

In Sasi system, some rules bind the people, the owner or products that are being Sasi. The rule prevents taking the products during Sasi. During the closing, the people are forbidden to take or consume natural resources and will be punished if breaking the rule. The penalty in Babar island is varied according to the following explanation from the respondents.

"Any break of Sasi, in taking results on-farm or plantation area will be penalized. The penalty will be set by the customary elders with payment using Basta cloth, gold, or animals."

(Y. M, custom figure of Wetang Island)
"During traditional Sasi in Luang Sermatang, the prayer by customary elders contains punishments to those who break the Sasi by mentioning their names in the prayer. For example, there will be stomachache, blood vomiting, etc for those who steal the Sasi products. If the sea products are stolen, then they will have an accident in the sea. If these penalties are experienced, they must immediately encounter with the owner or lawyer, apologize, and do a customary ritual to seek forgiveness."

(A. S, Luang Island community figure)

"Anyone who takes the farm or sea products which are being Sasi will be fined. If someone takes them secretly, it will be announced in the news on Sunday service at church and regular service. If someone takes and doesn't confess, therefore he will be prayer request of the assembly of the congregation."

(S. K, a community leader of Dawelor

Dawera)

\subsection{The Procedure and Sasi Ritual in Babar Island}

\subsubsection{The Ritual of Traditional Sasi}

\section{Closing Sasi Ceremony}

Traditional Sasi is done based on the agreement of the villagers (lek). It is started with a preparation ritual where all the villagers are in a traditional house (in Babar island, Wetang and Dawera Dawelor which is called Lakpona, in Masela island it is called Im). The custom elderly prepares all the offerings that will be presented. They are: 
(1) Sopi poured in shell

(2) A set of betel and betel nut

(3) A roll of tobacco.

All the materials are put into Nyiru (a flat round container to put the groceries) while saying the spell in their language (regarded as prayer), the customary chairman presents it to the spirits of ancestors and pleads that they should keep the sea products from those who would take or damage the sea.

After all the materials are complete, the chairman and all the villagers go to the shore to do worship ritual. The chairman drinks some of Sopi from the shell and pours the rest into the sea. Next, he throws one by one of the things in the Nyiru. This ritual of feeding and drinking the ancestors is believed as a pledge that the ancestors receive it and will take care of the sea products who have been kept.

After the Sasi Meti and Coconut, the area is marked with coconut leaves tied to a small tree and plugged in the middle of the coconut area. Meanwhile, the mark of Sasi Meti is small wooden trees or small tree stalks or coconut leaves tied to wood and plugged in the middle of Meti.

The materials of closing Sasi ritual in Luang and Sermatang islands are quite different from other villages in Babar islands. This is based on respondents' explanation as follows:

There are three main materials for doing Sasi of plantation products: Sopi, betel nut, and red ginger. Sopi is used in the ritual. Before it starts, the chairman lifts a glass of Sopi by explaining the purpose of the ritual and then drink it. After that, pass it to all who are involved in the ritual as a bound of fraternity and joint commitment. He then says the customary prayer. The process is ended by planting the red ginger in the corner of the plantation area and putting betel nut in the middle. Furthermore, the sign of "coconut leaf" is planted in the Sasi of the plantation.

If Meti and sea territory are in Sasi, the materials used are sopi and black stone. When the procession is done, the black stone is placed in the area of Meti where the "coconut leaf" is plugged as a sign that the Meti and the land area in the Sasi.

(A. S, Luang Island community figure)

\section{The opening ceremony of Sasi}

The culmination of the opening ceremony of Sasi is determined in two ways that follow the agreed time or adjust the sea products. Besides, the traditional Sasi can be considered complete and the result can be harvested if there is an urgent need to be addressed immediately. During the emergency, the chairman will hold a discussion to agree on the opening of customs clearance without violating the rules.

The opening ceremony begins with gathering all the people in Lakpona. Then, the chairman takes all the materials provided:

(1) Sopi poured in the shell

(2) A set of betel and areca nut

(3) One-roll tobacco

While pronouncing spells in their language, the chairman and the people go to the low tide area (meti). Next, he takes sopi and says the spells then drinks some of it and pour the rest of it into the water and follow by the things in nyiru. These things are the offerings for the ancestors who have kept and preserved the sea products during the traditional Sasi [17]. 


\subsubsection{The Church Sasi Ritual}

\section{The Closing Ceremony of Sasi}

The development of Christianity in Babar Island affects the way people do Sasi. It is done in a church way. The owner of the coconut area informs the location of doing Sasi to the leader of the church who will lead the procession. At Sunday worship, the assembly of the Church will inform the congregation and confirm it by prayer lead by the priest. Later, the owner of Meti or plantation area puts a sign of Sasi at the location, so that villagers and other citizens know and obey. As an offering of the church, the owner of a meti or an area of coconuts includes a certain amount of money in the offering box.

\section{The Opening Ceremony of Sasi}

The opening process is similar to the closing where the owner reports the leader of the church that the farm or garden or area of Sasi is ready to open and harvest. On Sunday service, the assembly informs through the church news and the priest will deliver the opening prayer. After church, the owner removes the sign and continue to do the harvest.

\subsubsection{The Values of Sasi Culture in Babar Island}

\section{Respect the environment}

The efforts to preserve the natural resources indicate that human needs the environment. The prohibition to take the plantation products and sea products in a certain period is a way of controlling and preserve the natural resources as well as a smart way in respecting the nature as a living and allow them to grow [13]. In other words, Sasi allows people not to behave randomly but builds a harmonious relationship with the natural environment which is also part of God's creature. Therefore, the human cannot live alone and needs other creatures to sustain life. The balance of the environment will be disrupted if living creatures damage one another. However, the community should treat nature properly and wisely. A great respect for nature that has contributed hospitalities to Southwest Maluku society is shown by the custom leaders, the heads of villages, church leaders, the rich, and the next generation with an intention of understanding the existence of natural environment as a part of their lives and transmit it to the people around them [15].

\section{Obey the traditional rules}

Sasi is a traditional rule that sets the connection between human and nature or human and human. As a traditional rule, some requirements have been made and agreed between the custom leaders, church, and the community. The agreements should be maintained and implemented by people without custom institution guidance. The people understand not to take the result of Sasi from the beginning until the end of Sasi procession. This indicates that the people in Babar island respect and obey the rules in doing Sasi. They believe that what has been entwined traditionally or in a Christian way has the power to weigh down those who break it [13]

The obedience of Babar island community toward the rules and the penalty of Sasi is not happening in its way. Many people have felt the impact they received if they took the coconut or sea product during Sasi. It indirectly becomes a lesson for those who follow the rules. This attitude gradually becomes a character of society. This value leads people to obey and follow every rule. 


\section{Togetherness and Mutual Sharing.}

Sasi done by a family or a clan is openned, all the people in that village or the neighboring village are given a chance to take the products in Sasi area. The traditional law of Maluku island defined the area of Meti is from shore until the limit of adult diving skill. When Sasi is opened for taking fish, shrimp, octopus, and others similar to them, the products taken belong to the person who acquired it. However, if the products are Lola, Batulaga, and Teripang which have economic value, the products are divided into two, $50 \%$ for the people who took and $50 \%$ for the owner of Sasi. This is a form of life sharing in togetherness.

\section{CONCLUSION}

Sasi is a prohibition to harvest certain resources (marine or land) in a certain period. Sasi aims to manage the result of planting and fishing in a certain territory, either yard or plantation area which gets the same treatment. The traditional laws are effective and make the people are not daring to take the results before time. The existence of Sasi brings a better quality of the ecosystem and natural resources. The Sasi products are well-preserved. Sasi brings a positive view for the people in Babar islands.

\section{Acknowledgement}

All the authors are grateful to Indonesia Ministry of Higher Education (RistekDikti) for their supports in this work.

\section{Conflict of Interest}

The researchers declare that they have no conflicts in all of their scientific collaboration.

\section{References}

[1]. J. Marantika, T. G. Ratumanan, and E. Kissiya, The Implementation of High School Local Content Learning in Babar Island, Science Nature 2(2), pp. 57-65 (2019). DOI: https://doi.org/10.30598/SNVol2Iss1pp057-065year2019

[2]. M.J. Saptenno, S. Sisinaru, E. Ubwarin, W.A. Siahaya, and H. I. Elim, Customary Law Associated with Five Integrated Aspects in Developing Traditional Coastal and Marine Protections for Improving Social People Life and Natural Products in Aru Islands Region of Maluku Province, Indonesia, Science Nature 2(2), pp. 105-113 (2019). DOI: https://doi.org/10.30598/SNVol2Iss2pp105-113year2019

[3] Cooley, F.L, Mimbar dan Tahta. Jakarta: Pustaka Sinar Harapan (1987).

[4] Creswell, John W. Penelitian Kualitatif dan Desain Riset, Memilih di Antara Lima Pendekatan. Edisi 3. Yogyakarta: Pustaka Pelajar (2014).

[5] Creswell, John W. Research design: Pendekatan Kualitatif, Kuantitatif, dan Mixed. Yogyakarta: Pustaka Pelajar (2013).

[6] Efemi, Nilda, Pengelolaan Lingkungan Hidup Melalui Pendekatan Ekosistem. Ambon: Dinas BUDPAR Prov. Maluku (2000).

[7] Hasanuddin, Kearifan Lokal dan Tradisi transformasi Konflik dalam Seni Ulu Ambek di Sumatera Barat. Padang: Universitas Andalas (2010).

[8] Haar. T, Asas-asas dan Susunan Hukum Adat. Terjemahan S.K. Ng. Porsponoto. Jakarta: PT Pradnya Paramita, (1979).

[9] Kontjaraningrat, Pengantar Antrhopology. Jakarta: Rineka Cipta, (2005).

[10] Kontjaraningrat. Pengantar Antrhopology: Pokok-pokok Etnografi. Jakarta: Rineka Cipta, (2011).

[11] Lokollo, J. E, Hukum Sasi di Maluku Suatu Potret Binamulia Lingkungan Pedesaan yang Dicari oleh Pemerintah. Orasi Dies natalis ke XXV Universitas Pattimura, Ambon (1988).

[12] Pattikayhattu, J. A. Sasi dan Kewang. Makalah disampaikan pada Workshop Kewang Sekecamatan Teluk Ambon Baguala dan Kecamatan Leitimur Selatan. Ambon: Yayasan Masnait (2007).

[13] Ratumanan. T. G, Marantika, J. R, Kissiya. E, Matitaputty, Ch. Buku Ajar Muatan Lokal Kelas XI. Ambon: Universitas Pattimura (2019).

[14] Ratumanan. T. G, Marantika, J. R, Kissiya. E, Matitaputy, Ch, Developing Local Content of Cultural Arts Learning Tools For VII Grade of Junior High School in Babar Islands Anticipating the Impact of the Blok Masela Management. Ambon: Makalah 
disampaikan pada International Seminar yang diselenggarakan oleh FKIP-Unpati (2018).

[15] Ratumanan, T. G., J. E. R. Marantika., Kissiya, E. The Inventory Culture of Babar Islands to the Local Content of SMP and SMA in Babar Islands (2017).

[16] Ratumanan, T. G., J. E. R. Marantika., Kissiya, E., Kurikulum Muatan Lokal untuk SMP dan SMA di Kepulauan Babar. Ambon: Universitas Pattimura (2017).

[17] Sahusilawane, S, Budaya Sasi Di Maluku. Dinas Kebudayaan dan Pariwisata Provinsi Maluku. Ambon (2001).
[18] Watloly, Aholiab., Fransina Matakena, Dominggus Saiya., \& Frans Dahoklory. Budaya Kalwedo di Maluku Barat Daya. Ambon: Balai Pelestarian Nilai Budaya (2012).

\section{'Corresponding Authors Brief CV:}

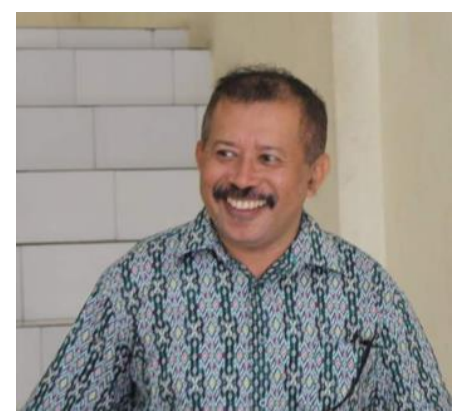

"Prof. Dr. Tanwey G. Ratumanan, S.Pd, M.Pd is one of the youngest Indonesia educational mathematicians. His professorship was awarded when he was just 38 year old. Prof. Ratumanan is currently working as a leading scientist in the Faculty of Education and Teacher Trainning called as FKIP at Pattimura university, Ambon, Indonesia. His office URL is http://s2pnd-matematika.fkip.unpatti.ac.id. The scientific profile of Prof. T.G. Ratumanan is recently highlighted in his Google Scholar profile: https://scholar.google.com/citations?user=xNdHwG4AAAAJ\&hl=en 